Jpn. J. Oral Biol., $40: 213-219,1998$.

\title{
ORIGINAL
}

\section{Secretory regulation by cholecystokinin in the rat submandibular gland}

\author{
Shinji Atsumi, Noriyasu Takai and Yo Yoshida \\ Department of Physiology, Osaka Dental University \\ (Chief : Prof. Yo Yoshida) \\ 8-1, Kuzuhahanazono-cho, Hirakata-shi, Osaka 573-1121, Japan
}

[Received on April 27, 1998 ; Accepted on May 26, 1998]

Key words : submandibular gland/cholecystokinin/secretion/autonomic nervous system

\begin{abstract}
The functional role of cholecystokinin (CCK) as a neurotransmitter or neuromodulator in the parasympathetic salivary secretion in the rat submandibular gland was examined. A continuous infusion (20 $\mu \mathrm{l} / \mathrm{min}$ ) of CCK octapeptide $(\mathrm{CCK}-8)$ at $10^{-12} \sim 10^{-8} \mathrm{M}$ through the glandular artery caused salivary secretion in a dose-dependent manner, and the maximal secretory response was obtained at $10^{-10} \mathrm{M}$. Atropine (cholinergic muscarinic antagonist, $1 \mathrm{mg} / \mathrm{kg}, i v$ ) reduced the salivary secretion induced by the infusion of $10^{-12} \sim 10^{-10} \mathrm{M}$ of $\mathrm{CCK}-8$, but not $10^{-9}$ or $10^{-8} \mathrm{M}$. The chorda (parasympathetic secretory nerve) was stimulated at various frequencies $(0.5 \sim 60 \mathrm{~Hz})$ before and after the administration of the CCK-antagonist, CR1409 $\left(10^{-4} \mathrm{M}\right)$. The salivary flow increased in a frequency-dependent manner, and the maximal responses were obtained at $20 \sim 40 \mathrm{~Hz}$ with or without the $\mathrm{CR}-1409$. The antagonist reduced the salivary flow at $20-60 \mathrm{~Hz}$, but had no effect at lower frequencies of $0.5 \sim 10 \mathrm{~Hz}$. The submandibular salivary flow, evoked by stimulation of the superior cervical ganglion (sympathetic secretory nerve), was not affected by the CCK-antagonist. Thus, CCK-8 may affect the submandibular acinar cells through at least two distinct pathways ; in the first, $\mathrm{CCK}-8$ stimulates the secretory response directly through the specific CCK receptor at the acinar cells (as a neurotransmitter). This pathway was blocked by a CCK-antagonist but not by atropine. Secondly, the effect of CCK-8 is modulated by interactions with the cholinergic receptor (as a neuromodulator). Immunohistochemical observations of CCK revealed that most nerve cell bodies within the submandibular ganglion were strongly CCK-positive and that some CCK-positive nerve fibers were distributed around acini in the gland. Both the immunohistochemical and physiological findings strongly suggested that the endogenous CCK directly and indirectly contributed to secretory regulation through parasympathetic innervation in the rat submandibular gland, with regard to the control of salivary fluid secretion.
\end{abstract}

抄録：ラット䫟下腺の神経性唾液分泌調節機構における神経伝達物質および神経調節物質としてのコレシスト キニン $(\mathrm{CCK})$ の役割について検討した。脳質内にCCK-8（1～10 $\mu \mathrm{g} ）$ を投与しても唾液分泌は見られないが, 顎下腺動脈からの投与では喠液分泌が見られた。その際, 低濃度のCCK-8 $\left(10^{-12} \sim 10^{-10} \mathrm{M}\right)$ による唾液分泌作用 は atropine $(1 \mathrm{mg} / \mathrm{kg}, i v)$ によって抑制されるが高濃度 $\left(10^{-9}, 10^{-8} \mathrm{M}\right)$ の CCK-8による分泌は抑制されなかっ た。高頻度 $(20 \mathrm{~Hz}$ 以上）の鼓策神経電気刺激（副交感性分泌刺激）による唾液分泌応答は CR1409（CCK 受容 体拮抗薬）によって抑制されたが低頻度の時には，この抑制効果は認められなかった。また，上頸神経節電気刺 激 (交感性分泌刺激)による分泌応答には CR1409による抑制効果は無効であった。免疫組織化学によって顎下神 経節内に CCK 陽性神経細胞, さらに腺房部周辺に陽性神経線維が観察された。これらの実験結果から CCK は唾 液水分の副交感性分泌調節において, 直接的には CCK 受容体を介した神経伝達物質として, そして間接的にはム スカリン性コリン受容体を介した神経調節物質として機能していると考えられる。 


\section{Introduction}

The main regulatory factors controlling the extent and nature of salivary gland secretions are autonomic neurotransmitters released by the innervation of both parasympathetic and sympathetic nerve terminals. The neurotransmitters provide the first messenger to a cell, signaling it to secrete. The binding of a neurotransmitter to a secretory cell surface receptor activates the receptor, and initiates the cascade of events resulting in salivary secretion. Several types of neurotransmitters or neuromodulators are considered to have some role in salivary gland secretion, including classical transmitters such as acetylcholine and noradrenaline, and some neuropeptides such as substance $P$, vasoactive intestinal polypeptide (VIP), calcitonin gene-related peptide, neuropeptide $\mathrm{Y}$ and enkeph$a^{1}{ }^{1,2)}$. Although muscarinic cholinergic receptors to which acetylcholine binds and adrenergic receptors to which noradrenaline binds have been studied in great detail and are considered to be the main functional receptors, little is known about the regulation of salivary secretion by the neuropeptides.

Cholecystokinin (CCK) is a hormonal regulator of gallbladder contractility and pancreatic enzyme secretion. CCK is thought to act as a neurotransmitter, centrally in the brain and peripherally in the enteric nervous system and at various gastrointestinal organs $^{3,4)}$. Regarding the salivary gland, Ruellan et al. ${ }^{5)}$ reported that $\mathrm{CCK}$ octapeptide (CCK-8) caused lipase secretion from the rat von Ebner's gland. Habara $^{6)}$ showed no comparable change in the rat parotid gland amylase release after treatment with CCK-8. Purushotham et al. ${ }^{7)}$ recently showed that CCK-8 alone does not influence the activities of amylase, protein kinase $\mathrm{C}$ and phosphatidylinositol 3kinase in the rat parotid gland. Although there are some reports of the effect of $\mathrm{CCK}-8$ on glandular enzyme activity in the salivary gland, effects of this peptide on salivary fluid secretion have not been reported. The present study examined the functional evidence of CCK as a neurotransmitter or neuromodulator in parasympathetic salivary secretion, using the rat submandibular gland. In a second series of experiments, the distribution of CCK-positive neurons within the rat submandibular gland and the related autonomic ganglions were examined immunohistochemically.

\section{Materials and Methods}

\section{Stimulation of the gland and drug admin- istration}

Male Wistar rats $(200 \sim 250 \mathrm{~g})$ were fasted for 12 hrs before the experiments but given free access to water, and then anesthetized with an intraperitonial injection of sodium pentobarbital $(50 \mathrm{mg} / \mathrm{kg})$. Additional doses of anesthetic were given through a femoral venous cannula when required. A tracheal cannula was inserted, and the body temperature was maintained at $37^{\circ} \mathrm{C}$ with the aid of a heating pad.

The submandibular saliva was collected through a polyethylene cannula (Intramedic PE10, Becton \& Dickinson, USA) inserted into the oral opening of the duct, as described by Takai et al. ${ }^{8)}$. The saliva samples were collected into micropipettes to measure the volume. Saliva was collected over 2 -min periods from the appearance of a saliva drop at the cannula tip. At the end of the experiment, the glands were dissected out and weighed. The amount of the secreted saliva was expressed in $\mu l$ of saliva per min per $100 \mathrm{mg}$ wet weight of the gland $(\mu \mathrm{l} / \mathrm{min} / 100 \mathrm{mg}$ gland).

For the secretory stimulation of parasympathetic and sympathetic nerves, the chorda on the excretory submandibular duct, and superior cervical ganglion, respectively were stimulated electrically with $3.0 \sim 5.0 \mathrm{~V}$ pulses at $20 \mathrm{~Hz}$ of $5.0 \mathrm{~ms}$ duration using a bipolar electrode.

As the agonist and antagonist, sulfated CCK-8 (Peptide Institute Inc. Japan) and CR1409 (Peninsula Lab. USA) ${ }^{9)}$ were used, respectively. The CCK-antagonist $\left(10^{-4} \mathrm{M}\right)$ and various doses of $\mathrm{CCK}-8$ were each dissolved in warm Ringer's solution, and administered separately by the technique described by Takai et $a l .{ }^{10)}$ to avoid systemic influences ; i. e., close infusion into the glandular artery using a Harvard syringe pump at a rate of $20 \mu \mathrm{l} / \mathrm{min}$, with all venous effluent discarded through the cannula inserted into the anterior facial vein. When Ringer's solution was infused at 
a rate of $20 \mu \mathrm{l} / \mathrm{min}$, there was no effect on the salivary secretion induced by chorda stimulation. The volume of blood loss was monitored and compensated by the addition of appropriate volumes of warm Ringer's solution through a cannula inserted into the femoral vein. Atropine sulfate $(1 \mathrm{mg} / \mathrm{kg})$ (Sigma, USA), a cholinergic muscarinic antagonist, was dissolved in Ringer's soultion and administered through the cannula inserted into the femoral vein $5 \mathrm{~min}$ before stimulation of the gland. In some cases the intracerebroventicular (icv) administration of CCK-8 (1 10 $\mu \mathrm{g} / \mathrm{rat}$ ) was tested.

Student's $t$-test was used for the statistical analysis of the data ; $p$-values less than 0.05 were considered significant.

\section{Immunohistochemistry for CCK}

The procedure for immunohistochemistry was essentially the same as described before ${ }^{11}$. Five male Wistar rats weighing approximately $150 \mathrm{~g}$ were perfused through the aorta with ice-cold saline containing $0.1 \%$ sodium nitrate and heparin, followed by 500 $\mathrm{m} l$ of Zamboni's fixative containing $2.0 \%$ paraformaldehyde and $0.2 \%$ picric acid in $0.1 \mathrm{M}$ phosphate buffer ( $\mathrm{pH}$ 7.4). The glands and superior cervical ganglion were dissected out and postfixed in the same fixative for $1 \sim 2$ days at $4^{\circ} \mathrm{C}$. The specimens were frozen and cut into $10 \mu \mathrm{m}$ sections on a cryostat and then mounted onto gelatin coated glass-slides.

After rinsing with $0.1 \mathrm{M}$ phosphate-buffered saline (pH 7.4, PBS), the sections were incubated for $24 \mathrm{hrs}$ at $4^{\circ} \mathrm{C}$ with a mixture of rabbit antiserum against CCK (Chemicon Inc, USA, $1: 10,000$ ) in $0.1 \mathrm{M}$ PBS. The sections were then rinsed with $0.1 \mathrm{M}$ PBS, and the primary antibody bound to the biotinylated second antibody (anti-rabbit IgG) was visualized using avidin-biotine-peroxidase (Vectastain $\mathrm{ABC}$ kit, Vector Labs, USA) with diaminobenzidine $-\mathrm{H}_{2} \mathrm{O}_{2}$.

Control experiments were carried out by incubation with the primary antiserum after preabsorption with $10^{-7} \mathrm{M} \mathrm{CCK}-8$. After this procedure, no positive nerve cell bodies were identified in the gland.

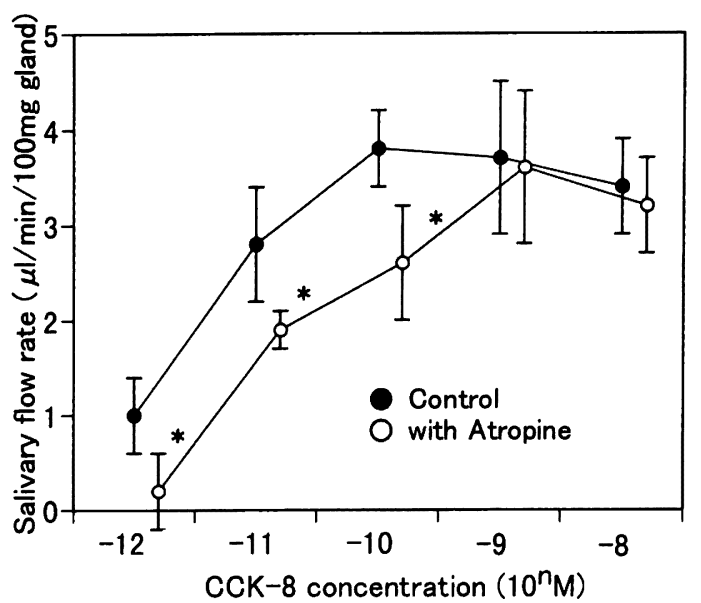

Fig. 1 Effect of atropine pretreatment on the submandibular salivary flow evoked by exogenous CCK-8 at various doses.

* Significantly different $(p<0.05)$ from CCK-8 stimulation alone (Mean $\pm \mathrm{SE}, \mathrm{n}=12)$.

\section{Results}

\section{Salivary Secretions}

There was no spontaneous secretion from the submandibular gland, and the $i c v$ administration of $\mathrm{CCK}^{-}$ $8(1 \sim 10 \mu \mathrm{g} / \mathrm{rat})$ caused no salivary secretion. The continuous infusion of CCK-8 $\left(10^{-12} \sim 10^{-8} \mathrm{M}\right)$ through the glandular artery evoked salivary secretion in a dose-dependent manner after a rather long latency (3 $\sim 5 \mathrm{~min}$ ). The maximal secretory response was $3.8 \pm$ $0.4 \mu \mathrm{l} / \mathrm{min} / 100 \mathrm{mg}$ gland of saliva at $10^{-10} \mathrm{M}$ of CCK8. Pretreatment with atropine partially inhibited the salivary secretion evoked by CCK -8 at $10^{-12} \sim 10^{-10} \mathrm{M}$, but not that at $10^{-9}$ and $10^{-8} \mathrm{M}$ (Fig. 1). The secretory responses by CCK $-8\left(10^{-12} \sim 10^{-8} \mathrm{M}\right)$ were completely abolished by the CCK-antagonist, CR1409.

The chorda was stimulated at various frequencies $(0.5 \sim 60 \mathrm{~Hz})$ before and after the administration of CR1409. The salivary flow increased in a frequencydependent manner, and the maximal responses were obtained at $20 \sim 40 \mathrm{~Hz}$ with or without the CCK-antagonist. The antagonist significantly reduced the salivary flow at 20,40 and $60 \mathrm{~Hz}$ by approximately $22 \%$ $(p<0.05), 34 \%(p<0.05)$ and $26 \%(p<0.05)$, respectively, but had no effect at the lower frequencies of $0.5 \sim 10 \mathrm{~Hz}$ (Fig. 2). The salivary flow evoked by 


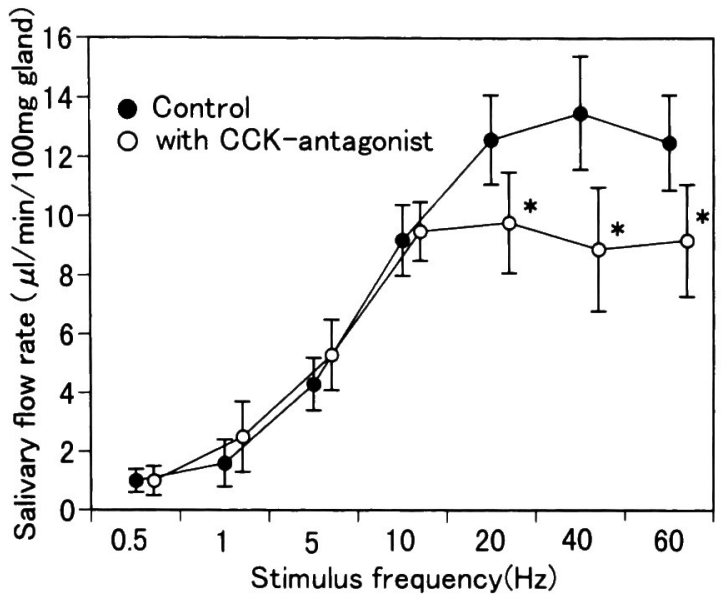

Fig. 2 Effect of CR1409 (CCK-antagonist) on the submandibular salivary flow rate evoked by electrical chorda stimulation at various frequencies.

* Significantly different $(p<0.05)$ from chorda stimulation alone (Mean $\pm \mathrm{SE}, \mathrm{n}=12$ ).

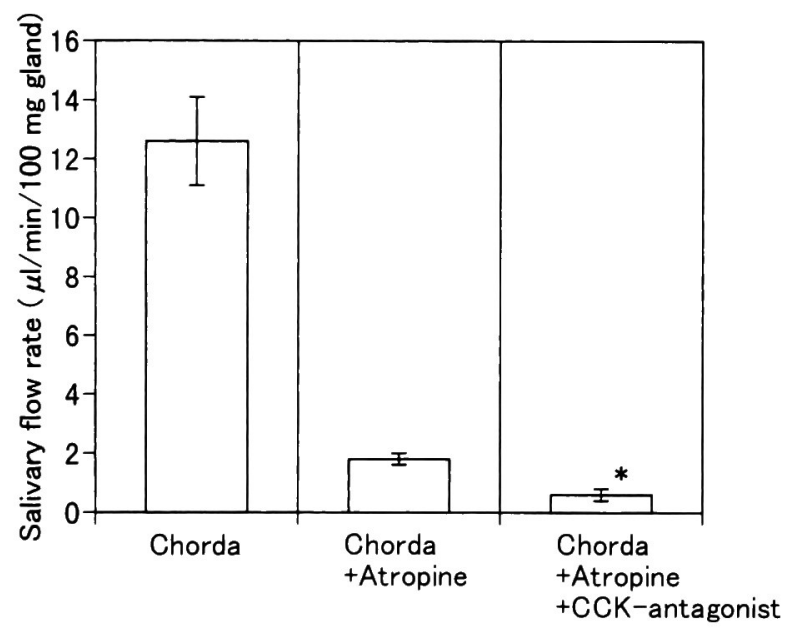

Fig. 4 Effect of CR1409 (CCK-antagonist) on atropineresistant parasympathetic secretion (chorda+ atropine).

* Significantly different $(p<0.05)$ from atropine-resistant secretion (Mean $\pm \mathrm{SE}, \mathrm{n}=5$ )

the stimulation of the superior cervical ganglion (sympathetic secretory nerve) at 20 and $40 \mathrm{~Hz}$ was not affected by the CCK-antagonist (Fig. 3). Such stimulation at low frequency $(5 \mathrm{~Hz})$ with and without the CCK-antagonist caused no salivary secretions.

The salivary flow produced by chorda stimulation at $20 \mathrm{~Hz}$ decreased to approximately $3 \%$ after atropine administration. The $\mathrm{CCK}$-antagonist signifi-

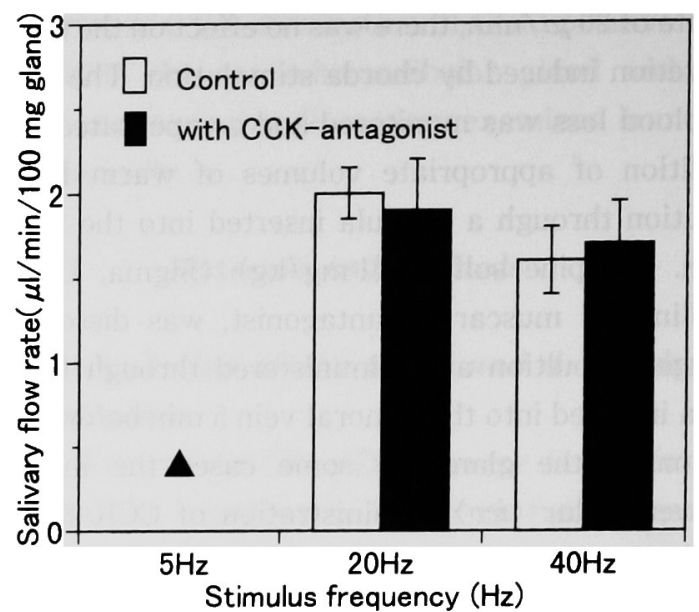

Fig. 3 Effect of CR1409 (CCK-antagonist) on the submandibular salivary flow rate evoked by electrical stimulation of the superior cervical ganglion (SCG) at 20 and $40 \mathrm{~Hz}$.

The values shown are Mean \pm SE $(n=5)$.

- SCG stimulation at $5 \mathrm{~Hz}$ with and without CR1409 evoked no salivation.

cantly $(p<0.05)$ reduced such atropine-resistant secretion (Fig. 4).

In another experiment, an exogenous CCK-8 (10 $10^{-12}$ and $10^{-10} \mathrm{M}$ ) infusion at the same time as chorda stimulation $(20 \mathrm{~Hz})$ caused a slight increase in the salivary flow compared with that for chorda stimulation alone. Conversely, higher doses of CCK-8 (10-8 and $10^{-6} \mathrm{M}$ ) infusion caused a decrease in the salivary flow by chorda stimulation (Fig. 5).

\section{CCK localization}

Figure 6 shows the localization of CCK like immunoreactivity in the rat submandibular ganglion (A) and submandibular gland (B). Within the submandibular ganglion located at the hilum of the gland, most nerve cell bodies were strongly CCK-positive. Some CCK-nerve fibers were distributed around acini in the gland.

\section{Discussion}

In the present study using the rat submandibular gland, we demonstrated that CCK-8 alone has a modest ability to stimulate salivary secretion. The secretory effect of CCK-8 on the acinar cells was local 


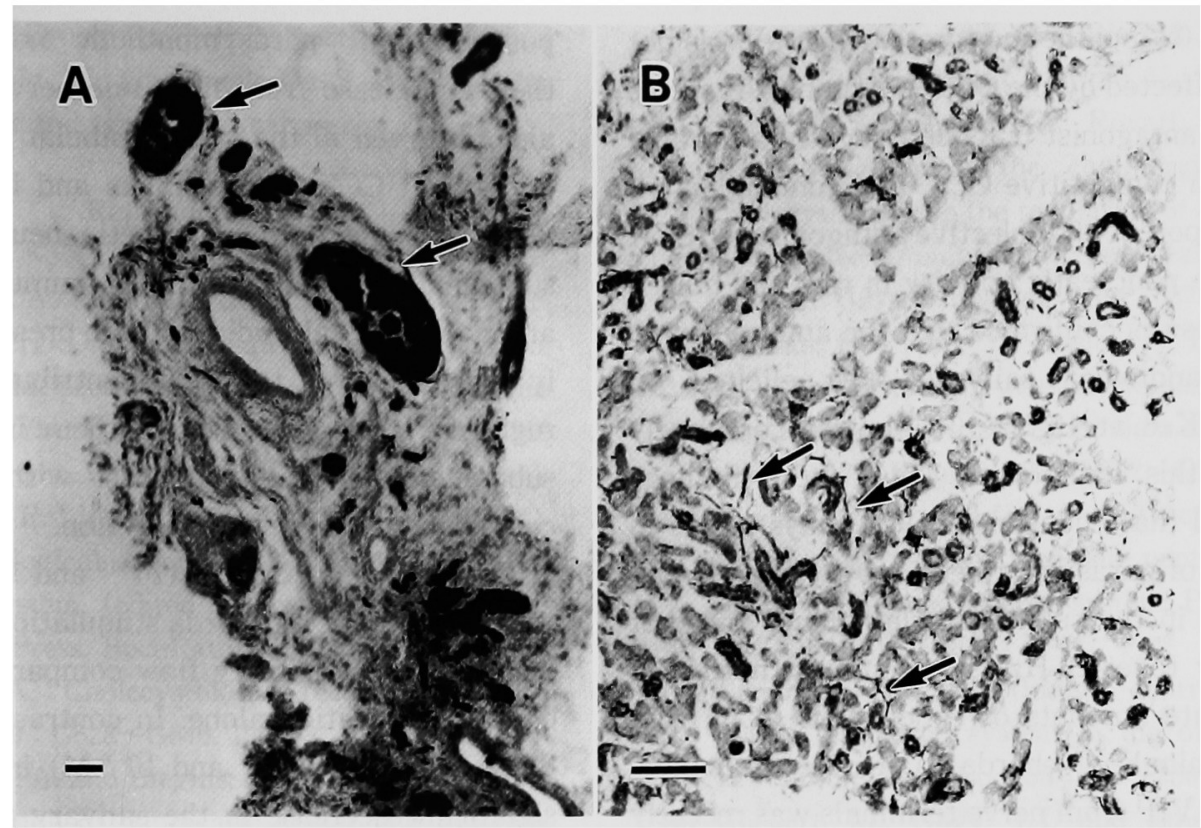

Fig. 6 Photomicrographs showing immunoreactivity for CCK in the rat submandibular ganglion and gland, Nerve cell bodies $(\uparrow)$ in the submandibular ganglion were strongly positive for CCK (A). Some CCK-positive nerve fibers $(\uparrow$ ) lie close to the acini (B). Bar $=100 \mu \mathrm{m}$.

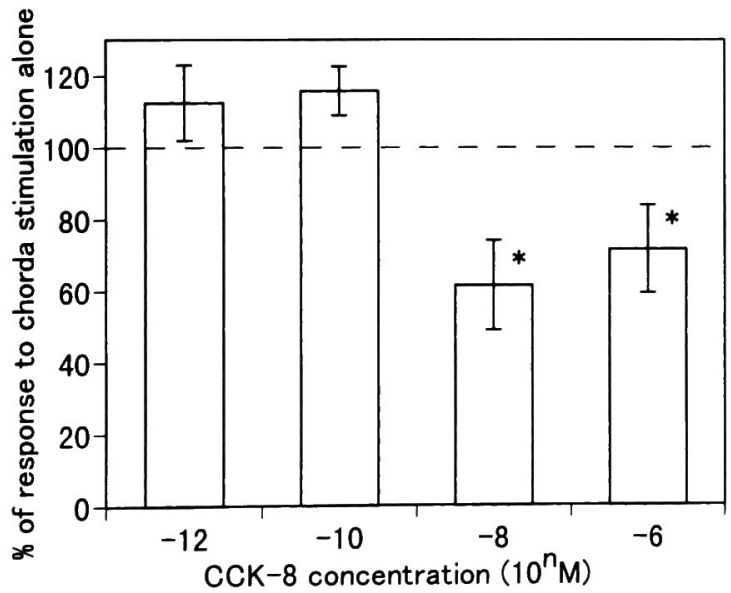

Fig. 5 Effect of exogenous CCK-8 on the submandibular salivary flow rate evoked by chorda stimulation at $20 \mathrm{~Hz}$.

* Significantly different $(p<0.05)$ from chorda stimula. tion alone (Mean $\pm \mathrm{SE}, \mathrm{n}=5$ ).

and direct because we employed the vascular isolated in vivo method for the agonist administration, and because the icv administration caused no salivary secretion.
Atropine inhibited the salivary secretion evoked by CCK-8 at low doses $\left(10^{-12} \sim 10^{-10} \mathrm{M}\right)$, but not at higher doses $\left(10^{-9}\right.$ and $\left.10^{-8} \mathrm{M}\right)$. Thus, CCK -8 may affect the submandibular acinar cells through at least two distinct pathways ; in the first, $\mathrm{CCK}-8$ stimulates the secretory response directly through the specific CCK receptor at the acinar cells (as a neurotransmitter). This pathway was blocked by the CCK-antagonist but not by atropine. Secondly, the effect of CCK-8 (as a neuromodulator) is modulated by interactions with the cholinergic receptor. Regarding the latter pathway, it has been reported that the inhibitory effect of atropine on CCK-8 induced an enzyme secretory response in the human exocrine pancreas ${ }^{12)}$ and CCK-8 evoked the release of acetylcholine from the rat pancreas ${ }^{13)}$.

In the present study, when the chorda was stimulated at low frequencies (less than $10 \mathrm{~Hz}$ ), the inhibitory effects of the CCK-antagonist were never seen. However, the CCK-antagonist partially inhibited the salivary secretion elicited by chorda stimulation at high frequencies (over $20 \mathrm{~Hz}$ ). Additionally, the salivary secretion evoked by stimulation of the superior cer- 
vical ganglion (sympathetic secretory nerve) was not significantly affected by the CCK-antagonist. It seems that this CCK-antagonist (CR1409), a glutaramic acid derivative with competitive $\mathrm{CCK}$-antagonistic activity, serves as a potent and selective antagonist for CCK in the exocrine pancreatic activity in rats and mice ${ }^{9)}$. The present results confirmed that the antagonism, i. e., the submandibular salivary flow elicited by exogenous CCK-8 at $10^{-12} \sim 10^{-8} \mathrm{M}$, was completely abolished by this antagonist. Thus, these findings clearly showed that endogenous CCK plays a role in the regulation of parasympathetic nerve-induced salivary secretion in the submandibular gland, and that high frequency (over $20 \mathrm{~Hz}$ ) stimulation is needed to release adequate amounts of endogenous CCK from the nerve terminals of chorda to secrete the saliva. The release of VIP from nerve terminals was recently reported to require a high-frequency stimulation of the chorda in the rat submandibular gland ${ }^{11}$. In contrast to the present in vivo findings of the rat submandibular gland, exogenous CCK -8 has been shown to be not potent in evoking an in vitro release of salivary enzyme in the rat von Ebner's gland ${ }^{6}$ and parotid gland $^{7}$. Organ differences might explain these conflicting results.

Although it has not been known whether the neurons within the salivary gland contain CCK, Lindh and Hökfelt ${ }^{14)}$ reported that some cholinergic secretomotor neurons contain $\mathrm{CCK}$ in the enteric nervous system. In the present study, some CCK-positive nerve fibers were distributed around acini in the submandibular gland. Most of the CCK-positive fibers showed a typical periacinar innervation pattern, which can be visualized by immunohistochemistry for many salivary transmitters and neuropeptides such as acetylcholine, VIP, substance $\mathrm{P}$, neuropeptide $\mathrm{Y}$ and calcitonin gene-related peptide (see review by Lundberg ${ }^{15)}$ ), suggesting that the CCK-positive fibers in the submandibular gland are secretomotor in nature. Additionally, the neural cell bodies in the submandibular ganglion, which supplies the parasympathetic innervation of acinar cells in the submandibular gland, were strongly reactive for CCK. It has been reported that acetylcholine and several neuropeptides including substance $\mathrm{P}^{16)}$ and $\mathrm{VIP}^{17}$ coexist in postganglionic parasympathetic nerve fibers, and their co-release from the same nerve terminals was also observed in the submandibular glands. It seems likely that CCK also coexists and is co-released in postganglionic parasympathetic neurons in the rat submandibular gland. Both the immunohistochemical and physiological findings in the present study strongly suggested that the CCK contributed to secretory regulation through parasympathetic innervation in the submandibular gland, at least with regard to the control of salivary fluid secretion.

The exogenous CCK-8 $\left(10^{-12}\right.$ and $\left.10^{-10} \mathrm{M}\right)$ infusion at the same time as chorda stimulation caused a slight increase in the salivary flow compared with that for chorda stimulation alone. In contrast to this, higher doses of CCK-8 $\left(10^{-8}\right.$ and $\left.10^{-6} \mathrm{M}\right)$ infusion caused a significant decrease in the salivary flow induced by chorda stimulation. The pathways involved in this inhibitory response are uncertain. In the rat submandibular gland, the cholinergic neurons contain an inhibitory neurotransmitter, $\gamma$-aminobutyric acid (GABA), and acinar cells express GABA receptor ${ }^{18)}$. The inhibitory action of CCK-8 may be involved in the parasympathetid GABAergic inhibitory mechanism. In support of this hypothesis, it was found that the $\mathrm{CCK}$ receptor is present in the cat sphincter of Oddi on the postganglionic inhibitory neurons ${ }^{19)}$.

Atropine-resistant parasympathetic secretion has been reported in the sheep parotid ${ }^{20)}$, ferret submandibular $^{21)}$ and rat submandibular ${ }^{14,22)}$ glands. Present findings support these observations, and further showed that the CCK-antagonist significantly reduced the atropine-resistant secretion. The atropine-resistant salivary secretion is non-adrenergic, noncholinergic, and can be explained as the release of several neuropeptides from postganglionic parasympathetic nerve terminals ${ }^{1,14}$. CCK is most likely one of these neuropeptides in the rat submandibular gland. The present results point to a complex interaction between the cholinergic system and CCK in salivary secretion. The interactions between CCK and other neuropeptides identified in the salivary gland merit further investigations.

We would like to express our gratitude to Drs. K. 
Uchihashi and K. Higuchi for their instruction and critical review of this paper. We also thank Ms. S. Yamaoka for her editorial work and typing the manuscript.

\section{References}

1) Titchen, D. A. and Reid, A. M. : Non-adrenergic, non-cholinergic control of salivary gland function. In : Epithelial secretion of water and electrolytes. (edited by Young, J. A. and Wong, P. Y.), pp. 219 〜28, Springer-Verlag, Berlin, 1990.

2) Garrett, J. R. : Innervation of salivary glands : Neurohistological and functional aspects. In: The salivary System. (edited by Sreebny, L. M.), pp.69 93, CRC Press, BocaRaton, 1987.

3) Wank, S. A. : Cholecystokinin receptors. Am. J. Physiol. 269 : G628〜G646, 1995

4) Williams, J. A. and Blevins, G. T. : Cholecystokinin and regulation of pancreatic acinar cell function. Physiol. Rev. 73: 701 723, 1993.

5) Ruellan, C., Moreau, J., Bouisson, M. and Ribet, A. : The Ebner glands: A. pancreatic-like gland secreting an acid lipase. Secretory regulation in vitro. Int. J. Pancreotol. 3 : 293 300, 1988.

6) Habara, Y.: Suppression of secretagogue-induced amylase secretion in pancreatic acini of coldexposed rats. J. Physiol. 414: 73 87, 1989.

7) Purushotham, K. R., Blazsek, J., Humphreys-Beher, M. G. and Zelles, T. : Cholecystokinin modulates isoproterenol induced changes in rat parotid gland. Comp. Biochem. Physiol. 106C : 249 254, 1993.

8) Takai, N., Yoshida, Y. and Kakudo, Y. : Technique for collection of saliva from the three major salivary glands of individual rats. J. Osaka Dent. Univ. 16: 17 23, 1983.

9) Makovec, F., Bani, M., Cereda, R., Chistè, R., Revel, L., Rovati, L. C., Setnikar, I. and Rovati, L. A. : Protective effect of CR 1409 (cholecystokinin antagonist) on experimental pancreatitis in rats and mice. Peptides $7: 1159 \sim 1164,1986$.

10) Takai, N., Yoshida, Y. and Kakudo, Y. : Secretion and re-absorption of glucose in rat submandibular and sublingual saliva. J. Dent. Res. $62: 1022 \sim 1025$, 1983.

11) Takai, N., Yoshida, Y., Shida, T., Kondo, E., Ueda, Y., Kiyama, H. and Tohyama, M. Expression of vasoactive intestinal polypeptide receptor mRNA and secretory regulation by vasoactive intestinal polypeptide in rat submandibular and sublingual salivary glands. Arch. Oral Biol. 42 : 197 204, 1997.

12) Adler, G., Beglinger, C., Braun, U., Reinshagen, M., Koop, I., Schafmayer, A., Rovati, L. and Arnold, $\mathrm{R}$.: Interaction of the cholinergic system and cholecystokinin in the regulation of endogenous and exogenous stimulation of pancreatic secretion in humans. Gastroenterology $100: 537 \sim 543,1991$.

13) Soudah, H. C., Lu, Y., Hasler, W. L. and Owyang, C. : Cholecystokinin at physiological levels evokes pancreatic enzyme secretion via a cholinergic pathway. Am. J. Physiol. 263 : G102 G107, 1992.

14) Lindh, B. and Hökfelt, T. : Structural and functional aspects of acetylcholine peptide coexistence in the autonomic nervous system. Prog. Brain Res. 84: 175 191, 1990.

15) Lundberg, J. M. : Peptidergic control of the autonomic regulation system in the orofacial region. Proc. Finn. Dent. Soc. 85 : 239 250, 1989.

16) Goedert, M., Nagy, J. I. and Emson, P. C. : The origin of substance $\mathrm{P}$ in the rat submandibular gland and its major duct. Brain Res. 252:327 333, 1982.

17) Johansson, O. and Lundberg, J. M. : Ultrastructural localization of VIP-like immunoreactivity in large dense-core vesicles of 'cholinergic-type' nerve terminals in cat exocrine glands. Neuroscience $5: 847$ $\sim 862,1981$.

18) Shida, T., Kondo, E., Ueda, Y., Takai, N., Yoshida, Y., Araki, T., Kiyama, H. and Tohyama, M. : Role of amino acids in salivation and localization of their receptors in the rat salivary gland. Mol. Brain Res. 33:261 268, 1995.

19) Behar, J. and Biancani, P. : Pharmacologic characterization of excitatory and inhibitory cholecystokinin receptors of the cat gallbladder and sphincter of Oddi. Gastroenterology 92: 764 770, 1987.

20) Reid, A. M. and Titchen, D. A. : Atropine-resistant secretory responses of the ovine parotid gland to reflex and direct parasympathetic stimulation. Q. J. Exp. Physiol. 73 : 413 424, 1988

21) Tobin, G., Ekström, J., Bloom, S. R. and Edwards, A. V. : Atropine-resistant submandibular responses to stimulation of the parasympathetic innervation in the anaesthetized ferret. J. Physiol. 437:327 $\sim 339,1991$.

22) Ekström, J., Månsson, B. and Tobin, G: Nonadrenergic, non-cholinergic parasympathetic secretion in the rat submaxillary and sublingual glands. Pharmcol. Toxicol. 60:284 287, 1987. 